\title{
Correction to: Erroneous Pagination in Volume 60, Issue 2 and Issue 3
}

Correction to: Statistical Papers (2019) 60(2):1-249 and 60(3): 251-669 https://doi.org/10.1007/s00362-019-01101-2; https://doi. org/10.1007/s00362-018-01073-9; https://doi.org/10.1007/ s00362-019-01095-x; https://doi.org/10.1007/s00362-01801070-y; https://doi.org/10.1007/s00362-018-01071-x; https://doi.org/10.1007/s00362-018-01077-5; https://doi. org/10.1007/s00362-018-01067-7; https://doi.org/10.1007/ s00362-018-01072-w; https://doi.org/10.1007/s00362-01801069-5; https://doi.org/10.1007/s00362-018-01063-x; https://doi.org/10.1007/s00362-018-01078-4; https://doi. org/10.1007/s00362-018-01081-9; https://doi.org/10.1007/ s00362-018-01082-8; https://doi.org/10.1007/s00362-01801062-y; https://doi.org/10.1007/s00362-018-01068-6; https://doi.org/10.1007/s00362-016-0840-1; https://doi. org/10.1007/s00362-016-0841-0; https://doi.org/10.1007/ s00362-016-0842-z; https://doi.org/10.1007/s00362-0160843-y; https://doi.org/10.1007/s00362-016-0845-9; https://

\footnotetext{
The original article can be found online at https://doi.org/10.1007/s00362-019-01101-2; https://doi. org/10.1007/s00362-018-01073-9; https://doi.org/10.1007/s00362-019-01095-x; https://doi.org/10.1007/ s00362-018-01070-y; https://doi.org/10.1007/s00362-018-01071-x; https://doi.org/10.1007/s00362-01801077-5; https://doi.org/10.1007/s00362-018-01067-7; https://doi.org/10.1007/s00362-018-01072-w; https://doi.org/10.1007/s00362-018-01069-5; https://doi.org/10.1007/s00362-018-01063-x; https://doi. org/10.1007/s00362-018-01078-4; https://doi.org/10.1007/s00362-018-01081-9; https://doi.org/10.1007/ s00362-018-01082-8; https://doi.org/10.1007/s00362-018-01062-y; https://doi.org/10.1007/s0036 2-018-01068-6; https://doi.org/10.1007/s00362-016-0840-1; https://doi.org/10.1007/s00362-016-08410; https://doi.org/10.1007/s00362-016-0842-z; https://doi.org/10.1007/s00362-016-0843-y; https://doi. org/10.1007/s00362-016-0845-9; https://doi.org/10.1007/s00362-016-0846-8; https://doi.org/10.1007/ s00362-016-0848-6; https://doi.org/10.1007/s00362-016-0849-5; https://doi.org/10.1007/s0036 2-016-0850-z; https://doi.org/10.1007/s00362-016-0851-y; https://doi.org/10.1007/s00362-016-0852-x; https://doi.org/10.1007/s00362-016-0853-9; https://doi.org/10.1007/s00362-016-0854-8; https://doi. org/10.1007/s00362-016-0855-7; https://doi.org/10.1007/s00362-016-0856-6; https://doi.org/10.1007/ s00362-016-0859-3; https://doi.org/10.1007/s00362-016-0860-x; https://doi.org/10.1007/s00362-01901096-w.
} 


\section{doi.org/10.1007/s00362-016-0846-8; https://doi.org/10.1007/ s00362-016-0848-6; https://doi.org/10.1007/s00362-016- 0849-5; https://doi.org/10.1007/s00362-016-0850-z; https:// doi.org/10.1007/s00362-016-0851-y; https://doi.org/10.1007/ s00362-016-0852-x; https://doi.org/10.1007/s00362-016- 0853-9; https://doi.org/10.1007/s00362-016-0854-8; https:// doi.org/10.1007/s00362-016-0855-7; https://doi.org/10.1007/ s00362-016-0856-6; https://doi.org/10.1007/s00362-016- 0859-3; https://doi.org/10.1007/s00362-016-0860-x; https:// doi.org/10.1007/s00362-019-01096-w}

Unfortunately, due to a technical error, the articles published in issues 60:2 and 60:3 received incorrect pagination. Please find here the corrected Tables of Contents. We apologize to the authors of the articles and the readers.

Corrected Table of Contents-Volume 60, Issue 2

\begin{tabular}{|c|c|c|}
\hline Article title & DOI & Page range \\
\hline $\begin{array}{l}\text { Editorial for the special issue mODa12: } \\
\text { Advances in Model-Oriented Design and } \\
\text { Analysis }\end{array}$ & https://doi.org/10.1007/s00362-019-01101-2 & $351-354$ \\
\hline $\begin{array}{l}\text { Adaptive designs for drug combination } \\
\text { informed by longitudinal model for the } \\
\text { response }\end{array}$ & https://doi.org/10.1007/s00362-018-01073-9 & $355-371$ \\
\hline $\begin{array}{l}\text { Asymptotic properties of maximum } \\
\text { likelihood estimators with sample size } \\
\text { recalculation }\end{array}$ & https://doi.org/10.1007/s00362-019-01095-x & $373-394$ \\
\hline $\begin{array}{l}\text { Randomization-based inference and the } \\
\text { choice of randomization procedures }\end{array}$ & https://doi.org/10.1007/s00362-018-01070-y & $395-404$ \\
\hline $\begin{array}{l}\text { Multi-part balanced incomplete-block } \\
\text { designs }\end{array}$ & https://doi.org/10.1007/s00362-018-01071-x & $405-426$ \\
\hline $\begin{array}{l}\text { Optimality of block designs under the model } \\
\text { with the first-order circular autoregression }\end{array}$ & https://doi.org/10.1007/s00362-018-01077-5 & $427-447$ \\
\hline $\begin{array}{l}\text { Optimal design of inspection times for inter- } \\
\text { val censoring }\end{array}$ & https://doi.org/10.1007/s00362-018-01067-7 & $449-464$ \\
\hline $\begin{array}{l}\text { Optimal designs for minimax-criteria in } \\
\text { random coefficient regression models }\end{array}$ & https://doi.org/10.1007/s00362-018-01072-w & $465-478$ \\
\hline $\begin{array}{l}\text { On the aberrations of mixed level orthogonal } \\
\text { arrays with removed runs }\end{array}$ & https://doi.org/10.1007/s00362-018-01069-5 & $479-493$ \\
\hline $\begin{array}{l}\text { Optimal designs for K-factor two-level } \\
\text { models with first-order interactions on a } \\
\text { symmetrically restricted design region }\end{array}$ & https://doi.org/10.1007/s00362-018-01063-x & $495-513$ \\
\hline $\begin{array}{l}\text { Locally D-optimal designs for a wider class } \\
\text { of non-linear models on the k-dimensional } \\
\text { ball... with applications to logit and probit } \\
\text { models }\end{array}$ & https://doi.org/10.1007/s00362-018-01078-4 & $515-527$ \\
\hline $\begin{array}{l}\text { Distribution of the multivariate nonlinear LS } \\
\text { estimator under an uncertain input }\end{array}$ & https://doi.org/10.1007/s00362-018-01081-9 & $529-544$ \\
\hline
\end{tabular}




\begin{tabular}{lll}
\hline Article title & DOI & Page range \\
\hline $\begin{array}{l}\text { Bregman divergences based on optimal } \\
\text { design criteria and simplicial measures of }\end{array}$ & https://doi.org/10.1007/s00362-018-01082-8 & $545-564$ \\
$\begin{array}{l}\text { dispersion } \\
\text { An unexpected connection between Bayes }\end{array}$ & https://doi.org/10.1007/s00362-018-01062-y & $565-584$ \\
$\begin{array}{l}\text { A-optimal designs and the group lasso } \\
\text { Optimal subsampling for softmax regression }\end{array}$ & https://doi.org/10.1007/s00362-018-01068-6 & $585-599$ \\
\hline
\end{tabular}

Corrected Table of Contents-Volume 60, Issue 3

Article title DOI

Page range

A marginalized multilevel model for bivari-

https://doi.org/10.1007/s00362-016-0840-1

$601-628$ ate longitudinal binary data

Classification rules based on distribution functions of functional depth

https://doi.org/10.1007/s00362-016-0841-0 629-640

Gini covariance matrix and its affine equivariant version

Some improved estimation strategies in high-dimensional semiparametric regression models with application to riboflavin production data

A Gini-based time series analysis and test for reversibility

Consistent nonparametric tests for detecting gradual changes in the marginals and the copula of multivariate time series

Testing for parametric component of partially linear models with missing covariates

Estimation based on progressively type-I hybrid censored data from the Burr XII distribution

Stochastic and ageing properties of coherent systems with dependent identically distributed components

Testing for zero inflation and overdispersion in INAR(1) models

Polya tree priors and their estimation with multi-group data

SB-robust estimation of mean direction for some new circular distributions

Classifi cation with the pot-pot plot

Some properties of cumulative Tsallis entropy of order a

https://doi.org/10.1007/s00362-016-0842-z 641-666

https://doi.org/10.1007/s00362-016-0843-y 667-686

https://doi.org/10.1007/s00362-016-0845-9 687-716

https://doi.org/10.1007/s00362-016-0846-8 717-746

https://doi.org/10.1007/s00362-016-0848-6

$747-760$

https://doi.org/10.1007/s00362-016-0849-5

761-803

https://doi.org/10.1007/s00362-016-0850-z

$805-821$

https://doi.org/10.1007/s00362-016-0851-y

$823-848$

https://doi.org/10.1007/s00362-016-0852-x

849-875

https://doi.org/10.1007/s00362-016-0853-9 877-902

https://doi.org/10.1007/s00362-016-0854-8 903-931

https://doi.org/10.1007/s00362-016-0855-7 933-943

https://doi.org/10.1007/s00362-016-0856-6 945-962

Logistic Liu Estimator under stochastic linear restrictions

Nonparametric tests for ordered quantiles

https://doi.org/10.1007/s00362-016-0859-3

$963-981$ 


\begin{tabular}{lll}
\hline Article title & DOI & Page range \\
\hline $\begin{array}{l}\text { Convergence rate of eigenvector empiri- } \\
\text { cal spectral distribution of large Wigner }\end{array}$ & https://doi.org/10.1007/s00362-016-0860-x & 983-1015 \\
matrices & & \\
$\begin{array}{l}\text { David A. Harville (2018): Linear Models } \\
\text { and the Relevant Distributions and Matrix }\end{array}$ & -w & 1017-1019 \\
$\begin{array}{l}\text { Algebra, Chapman and Hall/CRC, 524 pp. } \\
\text { xiii, \$135.00, ISBN: 978-1-138-57833-3 }\end{array}$ & & \\
\hline
\end{tabular}

Publisher's Note Springer Nature remains neutral with regard to jurisdictional claims in published maps and institutional affiliations. 